\title{
Correction: Do mitochondria play a role in remodelling lace plant leaves during programmed cell death?
}

\author{
Christina EN Lord, Jaime N Wertman, Stephanie Lane and Arunika HLAN Gunawardena*
}

\section{Correction}

Following the publication of this work [1] we became aware of errors in image selection from introductory Figure one. Figure one $\mathrm{C}[1]$ had been previously published as Figure one $\mathrm{C}$ in [2]; additionally Figure one F [1] had been previously published as Figure one E in [3]. This duplication of figures was inadvertent and we have now received permission from both publishers (Global Science Books [2] and Elsevier [3]) to reproduce these images. Note that these figures were for introductory demonstration purposes only, and this correction does not affect the scientific content of the article. We would like to apologize for any confusion or inconvenience this may have caused.

Received: 20 March 2013 Accepted: 20 March 2013

Published: 2 April 2013

\section{References}

1. Lord CEN, Wertman JN, Lane S, Gunawardena AHLAN: Do mitochondria play a role in remodelling lace plant leaves during programmed cell death? BMC Plant Biol 2011, 11:102.

2. Lord CEN, Gunawardena AHLAN: Isolation of Leaf Protoplasts from the Submerged Aquatic Monocot Aponogeton madagascariensis.

The Americas Journal of Plant Science and Biotechnology 2010, 4:6-11.

3. Carter J, Gunawardena AHLAN: Regeneration of the aquatic monocot Aponogeton madagascariensis (lace plant) through callus induction. Aquat Bot 2011, 94:143-149.

\section{doi:10.1186/1471-2229-13-58}

Cite this article as: Lord et al:: Correction: Do mitochondria play a role in remodelling lace plant leaves during programmed cell death?. BMC Plant Biology 2013 13:58.

\footnotetext{
* Correspondence: arunika.gunawardena@dal.ca

Department of Biology, Dalhousie University, 1355 Oxford Street, Halifax B3H
} 4R2, Canada

\section{Submit your next manuscript to BioMed Centra and take full advantage of:}

- Convenient online submission

- Thorough peer review

- No space constraints or color figure charges

- Immediate publication on acceptance

- Inclusion in PubMed, CAS, Scopus and Google Scholar

- Research which is freely available for redistribution (c) 2013 Lord et al.; licensee BioMed Central Ltd. This is an Open Access article distributed under the terms of the Creative Commons Attribution License (http://creativecommons.org/licenses/by/2.0), which permits unrestricted use, distribution, and reproduction in any medium, provided the original work is properly cited. 